\title{
Content and Language Integrated Learning (CLIL) Approach across Curriculum in Science Classrooms: Are the English Language Use and Learning Reveal?
}

\section{Nurhamsi Deswila1, Martin Kustati ${ }^{2} *$, Besral Besral ${ }^{2}$, Syayid Sandi Sukandi ${ }^{3}$}

\author{
${ }^{1}$ Monash University, Australia \\ ${ }^{2}$ Universitas Islam Negeri Imam Bonjol Padang, Indonesia \\ ${ }^{3}$ Southern Illinois University Edwardsville, America
}

*Correspondence to: martinkustati@yahoo.com

\begin{abstract}
The study aims to reveal the implementation CLIL approach in improving students' English language use and learning in the science classroom. A descriptive study was employed where data were collected using observation and interview to two classes at of Private Islamic Boarding in West Sumatera. The students for CLIL Strategy are the first grade of junior high school at science classrooms. The result of the research revealed that the use of the CLIL strategy across the curriculum is an effective strategy to develop English language use and learning. The pedagogical implications of the study for the EFL students in science classrooms include the need for teachers to consider underlying theories of teaching English in EFL context taking into account students' constraints; a focus on the various types of students' English ability and consider students' interest in topic selection; teachers to be aware of the significance of the relationship between their attitude and background in classroom practice; teachers to be trained formally on the implementation of the CLIL Strategy.
\end{abstract}

Keywords: assessment; content and language integrated learning; english language use and learning

Recommended citation: Deswila, N., Kustati, M., Besral, B., \& Sukandi, S. S. (2020). Content and Language Integrated Learning (CLIL) Approach across Curriculum in Science Classrooms: Are the English Language Use and Learning Reveal?. Journal of Innovation in Educational and Cultural Research, 1(1), 15-21

\section{INTRODUCTION}

Content and language integrated learning (CLIL) has been developed and implemented in Europe as an approach that is considered to be effective in teaching and learning. It has also been used in Australia in the form of JLT (Japanese Language Teaching) that helps students to learn the Japanese language. CLIL is the strategy that is recognized to be useful in the teaching of the second language (Lin, 2015). Due to the benefit of CLIL, Indonesia has also adapted CLIL in-school program in the form of the International class program in which English is used as a medium of instruction (Lee \& Chang, 2008; Turner, 2013). However, the International class program is only conducted by the private school since it has been diminished in public schools by the Indonesian government years ago. Private schools also find it is not simple to apply CLIL in the classroom for several reasons. According to (Hapsari, 2012), the challenge in the implementation of CLIL in Indonesia is the status of English as a foreign language that resulted in teachers' lack of English proficiency.

Although teachers of Islamic boarding schools use foreign languages, such as English and Arabic, in teaching and learning, English is still regarded as challenging (Bin Tahir, 2015; Hidayati, 2016; Lukens-Bull, 2001). Furthermore, teachers also should deal with the mastery of content and the ability in delivering the lesson through excellent communication (Darling-Hammond \& Baratz-Snowden, 2007; Hapsari, 2012). Given those challenges, the Indonesian teachers should find a suitable way to get the benefit of CLIL as it has been proven to be effective in the western country in improving student's language skills. Therefore, we would like to arrange a curriculum unit based on CLIL to teach science in a private Islamic Boarding school.

The curriculum is designed to teach science in English the context of Private Islamic Boarding School in West Sumatera. The students for CLIL approach are the first grade of senior high school in a science class. CLIL Strategy will be arranged for students two hours a week (one meeting). Students in this class are mostly from different cities in Sumatera islands with some students from other Islands like Java and Kalimantan etc. They are about 15-17 years old. Moreover, the students are multilingual who speak at least four different languages which are a vernacular language that depends on where the students come from (Minangkabau language, Pasaman language, Aceh language, etc.), Indonesian language, Arabic and English. They speak Bahasa Indonesia, Arabic and English in a formal communication at school and use local language with friends in an informal talk. Although they 
have different languages, they are all the same in religion which is Islam. Also, mostly these students come from a similar socio-economic background, middle to an upper level. Additionally, in terms of English proficiency, the students share similar abilities as they all come from the same junior high school.

The research intended to determine the implementation CLIL approach in improving students' English language use and learning in the science classroom. The study placed specific attention to English learning activities implemented in the science classrooms through CLIL. Learning activities are employed to develop students' linguistic and non-linguistic competences. To assist their linguistic competence, the activities should be designed to promote the students to use the language. Nevertheless, it is significant to design the CLIL Strategy carefully for them to benefit.

\section{METHODS}

The qualitative research was held at a private boarding school in West Sumatra. In this school, students are prepared to master both English and Arabic languages. In science classrooms, the teaching and learning process of English implements CLIL. It is because to reach the goal, and the students have to enrol courses which are delivered in English and Arabic languages. Both languages become compulsory subjects based on the national curriculum of secondary education in Indonesia and the internal curriculum implemented as a specific characteristic of boarding schools. Besides the frequency of the target language used in the instruction, which indicates that the classroom is CLIL. It focuses on both pedagogical and English language theories. It means that the students learn the theories of pedagogy as the content subjects with English as a foreign language that indicates CLIL implementation.

\section{Participants}

The subject of the research was 76 students who were involved in the CLIL strategy led science classrooms by using English. They actively participate in performing classroom activities. There were 40 female students (52.6\%) and 36 male students (47.3\%). The ethnic groups comprised Minang, Aceh, Bengkulu, Java, and Batak. The level of the students' English language proficiency was categorized as high proficiency $(14.3 \% ; n=10)$, average proficiency $(34.3 \% ; n=24)$, and low proficiency levels $(51.4 \% ; n=36)$.

\section{Instrument}

To get the data, the observation, interview, and documentation were done to determine how the CLIL was implemented teaching English in a science classroom. Observation is an instrument of data collection in which the situation of interest is watched, and the relevant facts, actions, and behaviours are recorded.

\section{Data Collection}

Data were collected through observation, interviews, and documentation. After the observation instrument and interview instrument are made, then the content is validated by the learning evaluation expert. Both instruments have received feedback and improvements from experts. Among all improvements, the most valuable is the instrument to explore deeply about the English learning process in the teacher and students in order to get more intact and complete information. The aspects were confirmed through interviews about the process of learning English in science learning, starting from the process of involving students to the assignments given by the teacher. The observation was carried out to collect data about interest in learning English, learning activities that fit the facts in class, forms of action in learning, and various student activities during the learning process.

\section{Data Analysis}

The results of the interviews were analyzed descriptively qualitatively by confirming respondents' statements and answers with the facts about English learning found during the observation process. The analysis was conducted on the form of learning interactions that occur from the results of interviews with observations for student-student and teacher-student interactions that are presented descriptively. The documentation obtained, from the learning planning and learning tools used during learning, was confirmed descriptively with the reality during the learning implementation in the class.

\section{RESULT AND DISCUSSION}

Although students of the first grade of private Islamic senior high schools in our context share some similarities, they also have differences. The students have already learned Basic English since junior high school. The schools also encourage the students to use English in their boarding program to improve their language skills. These potentials can support the implementation of CLIL Strategy in the classrooms. However, in terms of under- 
standing the content in English, they might find difficulties, so it is necessary to consider their understanding of the lessons. To address this issue, the classroom language use would be English and Indonesian Language, 50:50. Furthermore, the students have various learning styles and strategies to understand the lessons. Therefore, the teaching strategy should also accommodate the student's needs. Various activities such as group discussion, teacher's presentation, and questions and answers would be done in the classrooms. Also, the materials would be delivered in several forms such as pictures, videos, power points, and students' books. Those strategies are chosen to support CLIL effectively in teaching and learning.

The implementation of CLIL has concerned four main issues including the chosen topic, the stages of learning process, the language use and assessment. The topic Natural disaster is something related to the nature of West Sumatera in which kinds of disaster have attack the province. The use of the topis is useful for students to understand what natural disaster is and how they should behave to save themselves. Basically, there are three main stages of CLIL implementation which are teacher's introduction and explanation, students' activities, and assessments. Teacher firstly opened the classroom by reviewing previous lessons and or short discussion before explaining to topic and activities. Teacher used both English and Indonesia in this part. Teacher used English for introduction and the students understand the basic English excellently. However, when explaining the materials teacher used some English and emphasize by the Indonesian language. Students' activities vary in every meeting including pair work, groupwork, whole class discussion and project presentation. In doing their activity students can use both English and Indonesian language to avoid misunderstanding. However, students tend to use Indonesian language when they talk to their peers. Furthermore, teacher conducts the assessments of the CLIL classroom in final meeting to see students' achievements during the learning process.

Based on the observations in the classroom the implementation of CLIL can be divided into several interactions including students' interaction with the teacher, student's interaction with the topics (learning materials) and students' interaction with their friends. Firstly, students listened and understood teacher's explanation by English however, they response in Indonesian language. Teachers use English in the introductory part of the lessons and explain the topic in Bilingual, English, and Indonesian language. Teacher firstly explained by English and then translates the explanation into Indonesian language to emphasize the point to be understood by students. Students understanding can be seen by the way they response. They paid attention to the topic and ask questions. However, in asking questions they use Indonesian language. When the teacher asked the, to change the language they said they were afraid of making mistakes. The teachers answered students' questions in both English and Indonesian language (English first then translate into Indonesian language) and encourage the students to keep trying using English. This situation happened in several meetings for example, in the first meeting. The students deliver a question in Indonesian language " Mengapa Gempa sering terjadi di kampung kita, Miss?" in the English verse " Why does earthquakes happen many times in our country?". Students questions reflected that they understood the definition of Earthquake and how it happened, so they wonder what is so special with West Sumatera that Earthquake is commonly attack.

The teacher focuses on the understanding the topic and assist the students to use English to response to the classroom activities. Although students tend to use Indonesian language in responding the teacher, the teacher need to firstly address students understanding on the topic before the use of English. For example, in the third meetings, when the teacher reviewed the previous materials, students proposed their conclusion by Indonesian language. One student said "Jadi tsunami itu gelombang tinggi yang terjadi setelah gempa kan Miss?". The English version is "So we can say that the tsunami is high wave that attacks after the earthquake happened, is not it?

In responding the student, the teacher firstly verifies or confirms his statement and then encourages him to say the English version by mentioning the vocabularies regarding the issue such as high wave, and attack. However, the more meetings, the teacher also seems to use more the Indonesian language than English. Secondly, although students understand the lesson in English, they use Indonesian language to describe the topic. Students seem more comfortable using Indonesian language when they are discussing the topic. It is hard for teacher to ask them to switch their language to English. Teacher cannot push the students to keep use English since the understanding regarding the topic is more important. Thirdly, the students used Indonesian language to discuss the topic with their peers. Also, Students tend to use some local languages in their classroom activities with peers even if they know the Indonesian and English form of the words being spoken. Some activities that students do independently were pair work and group work. The students talk in their own language such as Minang language. It happened almost in all pair work and group work activities, the use of English in activities are very limited. However, in doing whole class discussion and project presentation students tried to use English. The students tried to use English when asking questions although after the teacher reminding them. Also, the students use English in presenting their project in front of the classroom but only for introductory part. They switch to the Indonesian language when it comes to their topic. Although the teacher has taught them the vocabularies, most of the time, students only smile and tried for once. Furthermore, regarding the CLIL assessment, the teacher conducted the assessment on the final meeting. The assessment is conducted by written test related to the topic being dis- 
cussed throughout the meetings. The students were given the paper test and answer the given questions. The questions are related to the materials they have studied. The teacher marks the paper and gives score to the students.

It also found that CLIL improved the students' language and content knowledge and their critical thinking skill because they should connect their concept of knowledge to the context of real life. The feedback given by their English teacher becomes important factor to develop their language skill and content of knowledge. In this context, CLIL will lay down teachers' feedback. It also will promote and scaffold students in learning English language.

The implementation of CLIL in the Indonesian context is still in the process of learning, especially in the private Islamic Boarding School of my context. There are many challenges that the education leaders well as the teachers face to adapt and implement CLIL in Indonesian Education. Classroom language use and assessment are the two items that become the debate in the context of the Islamic Boarding School. These two issues would be further discussed in the following section.

\section{Language use in the classroom}

The use of the language in the classroom in the CLIL Strategy becomes problematic in my chosen context due to several reasons. Firstly, the potential that the students are multilingual (the ability to speak various local languages, Arabic, Indonesian language and English) sometimes becomes a hindrance (Lie, 2017). The students often use different language to express their feeling and mind with peers in the classroom. Although they are encouraged to use English and Indonesian language, they might use local language or Arabic for their purposes. Thus, it is sometimes not clear about the difference between the CLIL classroom and the regular classroom. Secondly, as English is a foreign language in Indonesia, science teachers might have difficulties in delivering the lessons (Mattarima \& Hamdan, 2011; Sawir, 2005; Suparsa et al., 2017; Zaim, 2017). Not all science teachers have good English proficiency in teaching the science class. Despite those challenges, the foreign language that is decided to be used in CLIL Strategy is still English. It is because English is the most spoken language in the world that has become the language of globalization (Johnson, 2009; Kirkpatrick, 2011; Kramsch, 2014; Kumaravadivelu, 2012; Pašalić \& Marinov, 2008; Zhu, 2003). School leaders believe that the demand to be able to communicate in English is increasing day by day. Furthermore, the Indonesian language is the first language that is chosen to be used in CLIL as it is the national language that the students familiarize the most. Therefore, the language used in the classroom of CLIL Strategy in the Private Islamic Boarding School of is English and Indonesian. It is also admitted that some challenges are there to be addressed to improve the quality of teaching and learning, especially in CLIL.

Based on Coyle et al. (2010), CLIL is regarded as the approach of teaching that enables additional language learning and content learning. CLIL also allows language other than the first language to be used as a medium of instruction (Coyle, 2007; Dalton-Puffer, 2011; Lorenzo et al., 2010; Nikula et al., 2013). It is significant to consider the student's language proficiency to enable them to understand the content. It is impossible to teach the students by using a foreign language without the help of their language. According to (Lin, 2015), CLIL implementation allows the use of first and second language in the different stages of classroom activities. Therefore, in implementing CLIL in the context of the Private Islamic Boarding School, the first language, the Indonesian language is used to help students understand the content. The Indonesian language is mainly used in delivering the content that the students might have difficulties to understand. However, the student's response the teacher used Indonesian language even if they understood the English form. They seem more comfortable to use local languages or Indonesian language than English.

Furthermore, the balance of using first and second language is also significant to consider. According to Thomas-Sunesson et al. (2018), code-switching or trans-language can benefit the teacher to make the problematic content to be more understandable for the students. However, the teacher should be careful to avoid the overuse of the first language. Similarly, Lin (2015) argues that the difficulties foreign language may lead to the overuse of student's language. Therefore, based on Czura \& Papaja (2013) language model, Model B type B is suitable for the context of the Private Islamic boarding school. We argued that Model B type B in which English and Indonesian language is used in the same portion 50:50 enable effective CLIL Strategy in the classroom. Students can improve their English and learn science more dynamically. Moreover, this model allows the implementation of the bilingual program in which the two languages are used as the medium of instruction as well as enable the focus on content learning. However, the fact revealed different view in the field. The overuse of the Indonesian language is inevitable. The students even use their local languages with peers in the classroom to emphasise their understanding. 


\section{Assessment}

Assessment is the strategy to know the improvement of our students after specific learning programs that could be challenging especially in CLIL Strategy. As CLIL is the integration of teaching language and content, it has also to assess both language and content Bentley (2010). Doing assessment is a part of the whole teaching activities that might be challenging for the teacher, especially in the CLIL Strategy. In my chosen context, the issues of assessments are dealing with how to access and when is the right time to do the assessments. Also, the limited sources of guidance regarding CLIL become the obstacles in assessing CLIL implementation.

Assessment can be divided into two parts which are formative assessment and summative assessment (Banegas, 2012; Bentley, 2015). Formative assessment is the assessment for learning that can be done during the learning activity such as asking a question, giving feedback in group work, etc. (Baker, 2011; Bell \& Muhidin, 2009; Black et al., 2004; Nicol \& Macfarlane-Dick, 2006). Formative assessment is usually conducted in the informal situation which also called performance assessment (Nicol \& Macfarlane-Dick, 2006). Meanwhile, summative assessment is done to know students' achievement that is conducted at the end of the program (Baker, 2011). The form of summative assessment is formal which usually called standardized tests or final tests. Regarding assessment in CLIL teacher can do observation and ask questions to the students at the beginning of the CLIL Strategy (Mehisto \& Asser, 2007). This can be done by asking students prior knowledge about the topic that is going to be discussed in CLIL Strategy. Moreover, the teacher needs to support the students to be familiar with CLIL assessment as there two items that will be assessed which are language and). In doing the assessment, it is significant for the teacher to explain to the students the type of answer that is expected in the assessment (Dervin, 2010). For example, the students must know that the given questions should be answered in the form of open or closed, in short, or extended, etc. (Bentley, 2015). Therefore, the teacher needs to carefully consider every aspect of assessing the CLIL Strategy.

Regarding assessment in my chosen context, there are several issues to be highlighted. Firstly, it is not clear for teachers in the Private Islamic Boarding School the right way to assess CLIL Strategy. Secondly, the method to do the assessment is also problematic for teachers in my context. I argue that the lack of resources about CLIL is the primary cause of those issues. Teachers only consider the final test as the only assessment they can do.

Moreover, teachers do not document the formative assessment they have done because they think that that is a part of the everyday activity. Therefore, the progress of students in learning in CLIL Strategy is not monitored well. Also, in giving the summative assessment, teachers only rely on the content achievement of the students. They focus on how the students can understand the content of the materials and put little attention on the language assessment. Therefore, it is critical for education leaders in my context to prepare and give training to the teachers to conduct better CLIL Strategy. To achieve the best result of CLIL implementation, all stakeholders need to work together, including education leaders, teachers, and students.

\section{CONCLUSION}

It can be concluded that the process of teaching English in the EFL classroom, especially in the Private Islamic boarding school, did not fully match with the Principle of CLIL Strategy yet. The English teacher knows what CLIL is, but she did not apply some CLIL principles in her class appropriately. Overall, the process of teaching English was close to the traditional teaching of explanation strategy. This study indicates that classroom language use facilitate the students to increase their English language and comprehension on content subjects of science in English. The teacher's teaching strategies through pair, small group, discussion, simulation, and so on help them to achieve the learning goal that is acquiring the language and the content of teaching materials of science subjects.

It is suggested that the English teacher should implement the CLIL strategy in teaching English well. The teacher must improve students' skills in English. Not to implement the principles of CLIL in teaching English means ignoring the goal of language teaching. Thus, CLIL is the solution to the current problem faced by the teacher. CLIL is not only good theoretically, but it also has been proved from the previous studies such as (Hapsari, 2012; Lee \& Chang, 2008; Lin, 2015). It is suggested that the English teacher could catch the students' attention, create a student-centred activity and motivate them to be more active.

\section{REFERENCES}

Baker, C. (2011). Foundations of bilingual education and bilingualism (Vol. 79). Multilingual matters. 
Banegas, D. L. (2012). Integrating content and language in English language teaching in secondary education: Models, benefits, and challenges. Studies in Second Language Learning and Teaching, 2(1), 111-136.

Bell, M., \& Muhidin, S. (2009). Cross-national comparison of internal migration.

Bentley, K. (2015). CLIL scenarios with young learners. Teaching English to Young Learners: Critical Issues in Language Teaching with 3-12-Year-Olds, 91.

Bin Tahir, S. Z. (2015). Multilingual behavior of Pesantren IMMIM students in Makassar. Asian EFL Journal, 86, 45-64.

Black, P., Harrison, C., Lee, C., Marshall, B., \& Wiliam, D. (2004). Working inside the black box: Assessment for learning in the classroom. Phi Delta Kappan, 86(1), 8-21.

Coyle, D. (2007). Content and language integrated learning: Towards a connected research agenda for CLIL pedagogies. International Journal of Bilingual Education and Bilingualism, 10(5), 543-562.

Czura, A., \& Papaja, K. (2013). Curricular models of CLIL education in Poland. International Journal of Bilingual Education and Bilingualism, 16(3), 321-333.

Dalton-Puffer, C. (2011). Content-and-language integrated learning: From practice to principles? Annual Review of Applied Linguistics, 31, 182.

Darling-Hammond, L., \& Baratz-Snowden, J. (2007). A good teacher in every classroom: Preparing the highly qualified teachers our children deserve. Educational Horizons, 85(2), 111-132.

Dervin, F. (2010). Assessing intercultural competence in language learning and teaching: A critical review of current efforts. New Approaches to Assessment in Higher Education, 5, 155-172.

Hapsari, A. (2012). English bilingual education: The challenge of communication and cognition aspects of content language integrated learning (CLIL) In Indonesia. JEE, Journal of English and Education, 6(2).

Hidayati, T. (2016). English language teaching in Islamic education in Indonesia; challenges and opportunities. Englisia: Journal of Language, Education, and Humanities, 3(2), 65-82.

Johnson, A. (2009). The rise of English: The language of globalization in China and the European Union. Macalester International, 22(1), 12.

Kirkpatrick, A. (2011). English as an Asian lingua franca and the multilingual model of ELT. Language Teaching, 44(2), 212-224.

Kramsch, C. (2014). Teaching foreign languages in an era of globalization: Introduction. The Modern Language Journal, 98(1), 296-311.

Kumaravadivelu, B. (2012). Individual Identity, Cultural Globalization, and Teaching English as an International Language: The Case for an Epistemic Break: B. Kumaravadivelu. In Principles and practices for teaching English as an international language (pp. 17-35). Routledge.

Lee, B. C., \& Chang, K. S. (2008). An overview of content language integrated learning in Asian countries. Studies in English Education, 13(2), 166-184.

Lie, A. (2017). English and Identity in Multicultural Contexts: Issues, Challenges, and Opportunities. TEFLIN Journal, 28(1), 71-92.

Lin, A. M. (2015). Conceptualising the potential role of L1 in CLIL. Language, Culture and Curriculum, 28(1), 7489.

Lorenzo, F., Casal, S., \& Moore, P. (2010). The effects of content and language integrated learning in European education: Key findings from the Andalusian bilingual sections evaluation project. Applied Linguistics, 31(3), 418-442.

Lukens-Bull, R. A. (2001). Two sides of the same coin: Modernity and tradition in Islamic education in Indonesia. Anthropology \& Education Quarterly, 32(3), 350-372. 
Mattarima, K., \& Hamdan, A. R. (2011). The teaching constraints of English as a foreign language in Indonesia: The context of school based curriculum. Sosiohumanika, 4(2).

Mehisto, P., \& Asser, H. (2007). Stakeholder perspectives: CLIL programme management in Estonia. International Journal of Bilingual Education and Bilingualism, 10(5), 683-701.

Nicol, D. J., \& Macfarlane-Dick, D. (2006). Formative assessment and self-regulated learning: A model and seven principles of good feedback practice. Studies in Higher Education, 31(2), 199-218.

Nikula, T., Dalton-Puffer, C., \& García, A. L. (2013). CLIL classroom discourse: Research from Europe. Journal of Immersion and Content-Based Language Education, 1(1), 70-100.

Pašalić, M., \& Marinov, S. (2008). The english language and globalisation. Školski Vjesnik: Časopis Za Pedagogijsku Teoriju i Praksu, 57(3.-4.), 249-258.

Sawir, E. (2005). Language difficulties of international students in Australia: The effects of prior learning experience. International Education Journal, 6(5), 567-580.

Suparsa, I. N., Mantra, I. B. N., \& Widiastuti, I. A. M. S. (2017). Developing learning methods of Indonesian as a foreign language. International Journal of Social Sciences and Humanities, 1(2), 51-57.

Thomas-Sunesson, D., Hakuta, K., \& Bialystok, E. (2018). Degree of bilingualism modifies executive control in Hispanic children in the USA. International Journal of Bilingual Education and Bilingualism, 21(2), 197-206.

Turner, M. (2013). Content-based Japanese language teaching in Australian schools: Is CLIL a good fit? Japanese Studies, 33(3), 315-330.

Zaim, M. (2017). Implementing scientific approach to teach English at senior high school in Indonesia. Asian Social Science, 13(2), 33-40.

Zhu, H. (2003). Globalization and new ELT challenges in China. English Today, 19(4), 36. 